\title{
Barrier-free environment as an aspect for the development of accessible ecotourism
}

\author{
Dmitry Gura ${ }^{1}$, Nadezhda Kiryunikova ${ }^{1}$,Elina Lesovaya ${ }^{1}$, and Saida Pshidatok ${ }^{2}$ \\ ${ }^{1}$ Kuban State Technological University, Moskovskaya Str. 2, 350072, Krasnodar, Russia \\ ${ }^{2}$ Kuban State Agrarian University, Kalinina Str. 13, 350044, Krasnodar, Russia
}

\begin{abstract}
Nowadays, in the entire palette of famous types of tourism, accessible ecotourism is one of the most promising ones. This area of tourism plays an important social role in the life of people with physical disabilities. Thanks to accessible ecotourism, the environment for people with disabilities is expanding. The paper analyzes the development of accessible tourism using the example of Krasnodar and the Krasnodar Krai, actualizes the need for the development of this type of tourism and establishes its importance for people with disabilities. It was revealed that it is necessary to carry out the state policy of the field of accessible tourism and plan the development of this sector at the state and regional levels using advanced information technologies. Routes that will be equipped with the necessary equipment for a comfortable moving and stay of people with disabilities are presented. The project approach allowed developing a model of mobile application for the development of accessible ecotourism in the Krasnodar Krai and throughout the whole country with the inclusion of all interested authorities in the solution of the problem, pooling the necessary resources and social survey. The results of the study and the experience of personal participation of the authors are given in this paper.
\end{abstract}

\section{Introduction}

Tourism - temporary trips (travel) of citizens of the Russian Federation, foreign citizens and stateless persons from a permanent place of residence for recreational, educational, professional, business, sports, religious and other purposes without paid activity in the country of temporary residence. Currently, special attention is paid to people with disabilities [12]. Since the problem of transportation and accommodation of people with disabilities is relevant today, it is proposed to create special tours in which these problems will be solved. According to the UN, there are about 650 million people with disabilities in the world (about 10\%), in Europe, people with disabilities make up $22 \%$ to $37 \%$ of the population (Eurostat, 2018) - only 60 million. 13.074 million people with disabilities live in Russia (Russian Federal State Statistics Service, 2018) [2]. People with disabilities travel less actively than other EU citizens: from $37 \%$ in the UK to 53\% in Germany. Meanwhile, $11 \%$ of all tourist trips in Europe and $7 \%$ - all over the world are made by travelers with special needs, most often together with family members or friends [5].

\footnotetext{
* Corresponding author: gda-kuban@mail.ru
} 
The French newspaper Le Monde says that Russia simply does not have any devices for the normal life of wheelchair users. French journalists have estimated that there is one special elevator per 800,000 Russian disabled people [17].

Disability is a social phenomenon that no society can avoid. Each state, in accordance with the level of its development, priorities and opportunities, forms its social and economic policy regarding disabled people [1]. The main concern of the state in relation to older people and people with disabilities is their material support, i.e. pensions, allowances, benefits, etc.

The system of social protection of persons with disabilities should be reoriented to their specific needs and requirements. People should receive social assistance and support, regardless of whose competence it is to provide this assistance. Disabled people have different needs, but they all have one thing in common: they need the support of the state, especially in the development of information and communication technologies [3].

\section{Methods}

During 2017-2019, the resorts of the city of Krasnodar and the Krasnodar Krai were analyzed. It was found that most resorts in this region are not suitable for people with disabilities. Disabled people are people like everyone else who wants to move around the street without barriers, travel comfortably, relax, attend various events unhindered, etc.

To make sure that the problem is relevant, a survey was conducted among 2,000 residents of the city of Krasnodar. Two questions were brought up for discussion: about the presence of people with disabilities in the family or among acquaintances, and about the country's adaptability to accessible tourism. The survey results are presented in Figures 1 and 2.

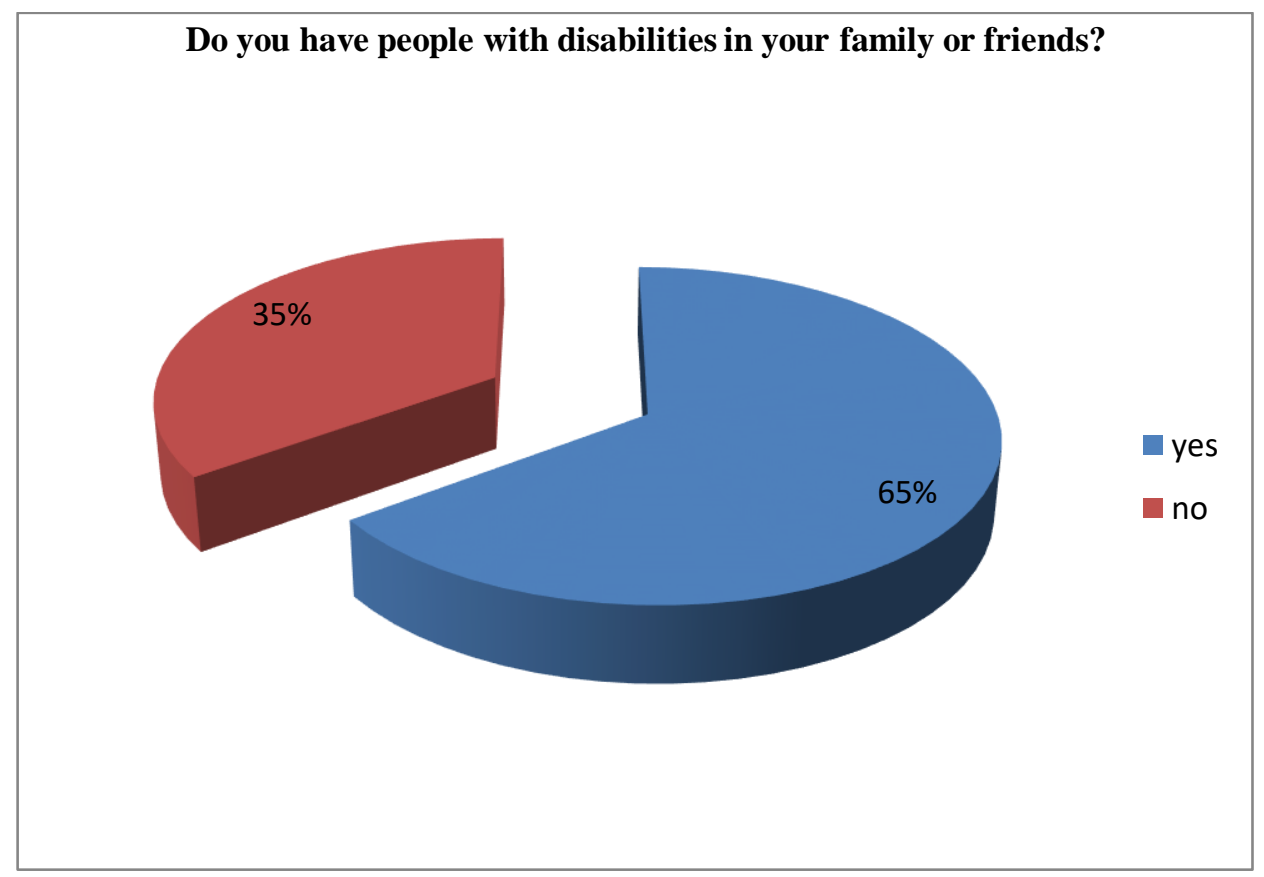

Fig. 1 Percentage of families with disabilities. 


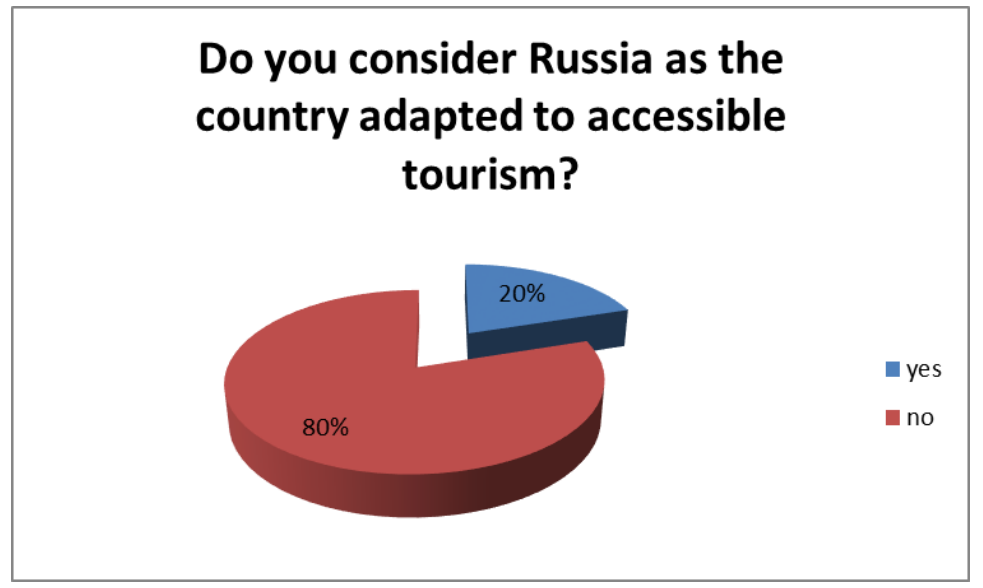

Fig. 2 The country's adaptability to accessible tourism.

The survey showed that the problem of transportation and accommodation of people with disabilities is relevant today. Therefore, it is proposed to create special tours in which these problems will be solved. A specialized sightseeing tour is built on the basis of the same components as the tour for ordinary tourists (organizing accommodation, meals, sightseeing transport, developing a program taking into account stops, preparing guides), but with the condition that all components are adapted to the needs of people with disabilities, as well as the use of advanced information technologies:

- the hotels organize accommodation in specialized rooms, more spacious than standard rooms, and with at least wider doorways, with all the necessary handrails and a "shower on the floor" in the bathroom;

- excursion transport is equipped with a specialized elevator or ramp;

- all museum and cultural objects under the program are accessible (must have adequate ramps, lifting devices, elevators) and have a specialized toilet;

- catering facilities are available and have a specialized toilet;

- stops are provided along the route (accessible public toilets);

- the guides are prepared, have up-to-date information on the availability of facilities, can navigate in case of spontaneous desires of tourists (unexpectedly needed a toilet, tourists are hungry, it is necessary to replace the object to visit, etc.).

Below are options for possible sightseeing tours adapted for people with disabilities in the form of tables 1-3.

Table 1. Off-season tour.

\begin{tabular}{|c|c|c|c|c|c|}
\hline ROUTE & $\begin{array}{c}\text { POINT OF } \\
\text { DEPARTURE }\end{array}$ & $\begin{array}{c}\text { DEPARTURE } \\
\text { TIME }\end{array}$ & ARRIVAL TIME & DISTANCE & ATTRACTIONS \\
\hline $\begin{array}{l}\text { Krasnodar- } \\
\text { Mostovskaya }\end{array}$ & $\begin{array}{l}\text { Krasnodar (bus station } \\
\text { Krasnodar - 1) }\end{array}$ & $10: 30$ & $\begin{array}{l}\text { 13:30 } \\
14: 00 \quad \text { (taking } \\
\text { into account } \\
\text { traffic jams) }\end{array}$ & $209 \mathrm{~km}$ & $\begin{array}{l}\text { - Victory Park } \\
\text { - Tornado Fountain } \\
\text { - Lake Upper } \\
\text { Kardyvach }\end{array}$ \\
\hline
\end{tabular}


Table 2. Summer tour.

\begin{tabular}{|c|c|c|c|c|c|}
\hline $\begin{array}{l}\text { ROUTE } \\
\end{array}$ & $\begin{array}{c}\text { POINT OF } \\
\text { DEPARTURE }\end{array}$ & $\begin{array}{c}\text { DEPARTURE } \\
\text { TIME }\end{array}$ & ARRIVAL TIME & DISTANCE & ATTRACTIONS \\
\hline $\begin{array}{l}\text { Krasnodar } \\
\text { Gelendzhik }\end{array}$ & $\begin{array}{l}\text { Krasnodar (bus } \\
\text { station } \\
\text { Krasnodar - 1) }\end{array}$ & $12: 30$ & $\begin{array}{l}14: 40 \\
15: 10 \quad \text { (taking } \\
\text { into account } \\
\text { traffic jams) }\end{array}$ & $186 \mathrm{~km}$ & $\begin{array}{l}\text { - Gelendzhik Bay } \\
-\quad \text { Seafront } \\
\text { Gelendzhik } \\
\text { - Safari Park } \\
\text { - Park "Olympus" } \\
\text { - Gelendzhik } \\
\text { Dolphinarium } \\
\text { - Oceanarium }\end{array}$ \\
\hline $\begin{array}{l}\text { Gelendzhik } \\
\text { Novorossiysk }\end{array}$ & $\begin{array}{l}\text { Gelendzhik } \\
\text { (bus station) }\end{array}$ & 11:00 & $\begin{array}{l}11: 40 \\
12: 10 \quad \text { (taking } \\
\text { into account } \\
\text { traffic jams) }\end{array}$ & $41 \mathrm{~km}$ & $\begin{array}{l}\text { - The cruiser } \\
\text { "Mikhail Kutuzov" } \\
\text { - Planetarium named } \\
\text { after M.Yu. Gagarin } \\
-\quad \text { Admiral } \\
\text { Serebryakov } \\
\text { Embankment } \\
\text { - Lake Abrau }\end{array}$ \\
\hline $\begin{array}{l}\text { Novorossiysk } \\
\text { Anapa }\end{array}$ & $\begin{array}{l}\text { Novorossiysk } \\
\text { (bus station) }\end{array}$ & $13: 30$ & $\begin{array}{l}14: 30 \\
15: 00 \quad \text { (taking } \\
\text { into account } \\
\text { traffic jams) }\end{array}$ & $51 \mathrm{~km}$ & $\begin{array}{l}\text { - embankment } \\
- \text { Anapa } \\
\text { Archaeological } \\
\text { Museum } \\
\text { "Gorgippia" } \\
\text { - Museum of Local } \\
\text { Lore } \\
\text { - Castle "Lion Head } \\
\text { in Sukko" } \\
\end{array}$ \\
\hline
\end{tabular}

Table 3. Winter tour.

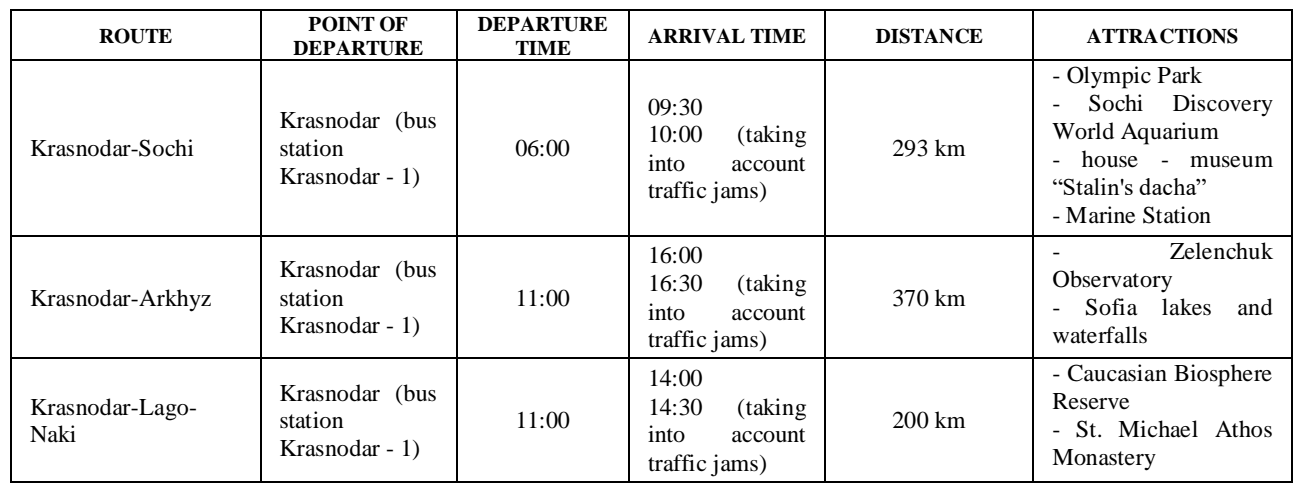

Marketing research was conducted. It was clarified how people learn about the tour. The answers of most respondents were as follows:

- start advertising on all information platforms;

- development of the application (+ version for the visually impaired);

- word of mouth. 


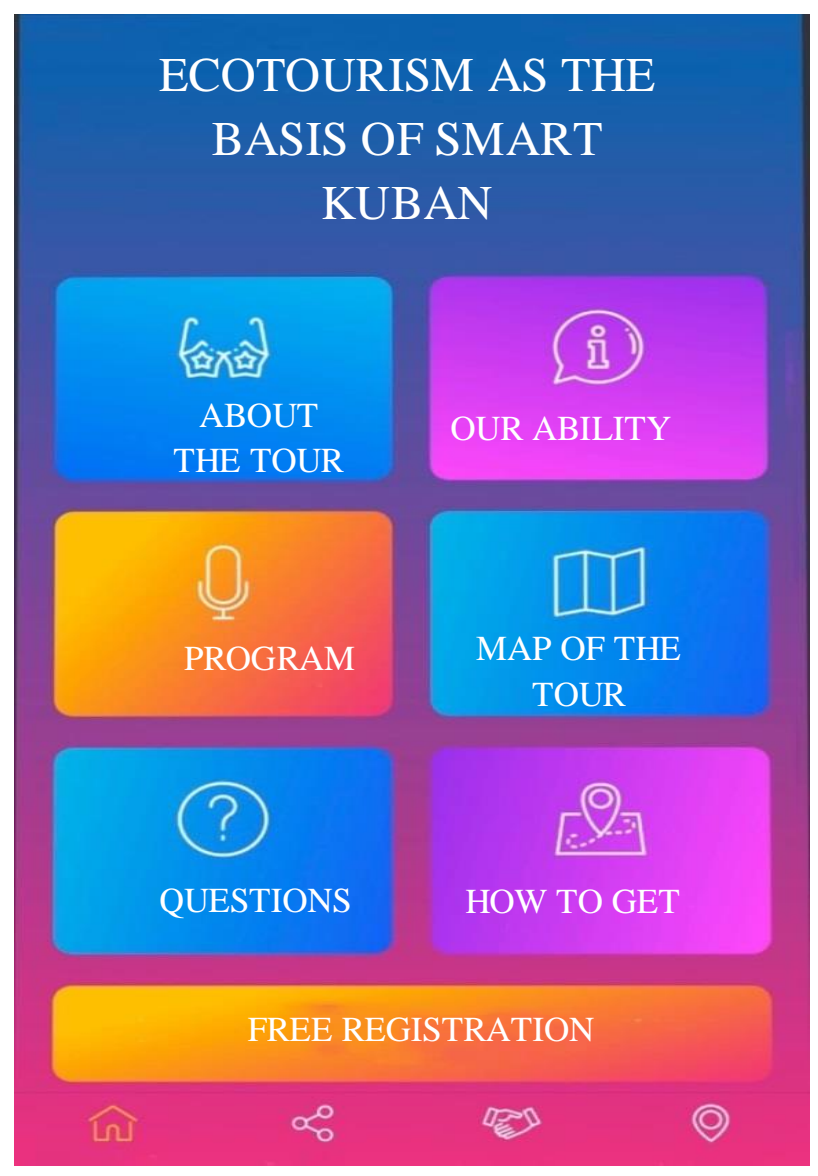

Fig. 3 Mobile app Model.

The research team has developed a mobile application interface model (Fig. 3).

Here you can get acquainted with the proposed routes (if necessary, create your own and view its options). In addition, application users will be able to ask all questions of interest to which tour managers will answer in the shortest possible time. This application has the function of choosing the type of entertainment program: outdoor activities, orientation and combined. If necessary, it is possible to order a transfer within the municipality to the place of departure to the tour for free [21].

One of the most important tasks when planning a tour for people with disabilities is the automatic selection of medical centers that meet all the requirements for ensuring a comfortable stay, rest and treatment. During the analysis, it was concluded that among the many medical centers of the Krasnodar Krai, only $1 / 3$ is adapted for use by people with disabilities. Therefore, it is proposed to create a medical center in the city of Krasnodar, where the necessary medical assistance will be provided to people with disabilities, and also the issuance of tours with a discount of $70 \%$ for people with disabilities (30\% paid by the buyer, $70 \%$ - by the state). The situation with transport in the city is no better, therefore it is proposed to create a transfer network - which will be:

a) free of charge to deliver vacationers from the airport/railway (bus) station to the recreation center;

b) equipped with all necessary equipment for the transportation of disabled people of all groups. 


\section{Results}

The development of this project involves the creation of a comfortable urban barrier-free environment, thereby creating access for people with disabilities. The estimated duration of the project is 10 years.

If this project will be implemented in the future, and there will also be an increase in tourists with disabilities with an annual progression of 5-7\%, then by 2030, Krasnodar will become the tourist and cultural capital of Russia, and Krasnodar Krai will become the standard of comfortable life for people with disabilities.

\section{Discussions}

Consumers of services of accessible tourism can be not only people with disabilities, but also their families, guardians and specially trained accompanying people [5]. The type of tourism is selected depending on the physical limitations of the tourist, his personal interests, desires, financial capabilities, expected rehabilitation results. Inclusive tours aim at the rehabilitation and adaptation in society of people with disabilities, the elderly and the disabled people [7, 22]. Communication and just being in a group uncover, remove the feeling of anxiety and helplessness, depression, help to make friendships. With all this, the main thing remains the attitude in society towards people with disabilities. It is indifference and negative attitude that leads to the separation of such people into special groups, which subsequently often leads to discrimination [20,23]. Inclusive tours are especially important for the socialization of wheelchair users, because due to the frequent lack of access to the street, this category of citizens does not integrate into society [10, 24]. For wheelchair users, a tour of several days is a turning point in life, which radically changes a person's horizons, his mental and emotional state $[12,25]$.

\section{Conclusions}

The main criterion according to which persons with disabilities choose a particular tourist route is the accessibility of the environment [19]. In this regard, the formation of a tourism environment that meets the needs of all traveling citizens regardless of their age and sex characteristics, their education and social status should be a promising task for the development of accessible tourism. [6]. In the Russian Federation, the design of tourism products taking into account the needs of a special category of tourists should become the norm. However, in order to overcome the contradictions between the desires and capabilities of the tourism industry, it is necessary to ensure the full realization of the tourism potential of the regions, translating their potential capabilities into production factors actually used in the tourism industry [13].

After analyzing, it was revealed that tourism for people with disabilities is currently not developed and does not have a training system for personnel. Tourism development for people with disabilities without state support seems unlikely, since the functional problems of this tourism sector are significant [15].

\section{References}

1. S.V. Badanina, Via scientiarum - The Road of Knowledge, 1, 39-43 (2015)

2. E.V. Bochkova, Scientific and methodological electronic journal "Concept",15, 14061410 (2016)

3. G. Shaw, Tourism Management, 25, 149-162 (2019) 
4. D. Sedgley, Annals of Tourism Research, 66, 14-25(2017)

5. I.V. Klimova, Culture and time of changes, 2 (21), 15 (2018)

6. O.S. Kogan, Vestnik UGUES. Science, education, economics. Series: economics, 3 (13), 22-24 (2015)

7. E.I. Konanova, Interdisciplinarity in modern socio-humanitarian knowledge, 642-652 (2016)

8. A.I. Letin, Successes in modern science and education, 2(2), 140-142 (2017)

9. L.A. Mezhova, Modern problems of science and education, 1(1), 1108 (2015)

10. T.M. Poddubnaya, Integrated communications in sport and tourism: education, trends, international experience, 2, 243-245 (2018)

11. R. Pagan, Annals of tourist research, 39(3), 1514 - 1537 (2012)

12. S. Darcy, Tourism Management, 31(6), 816-826 (2010)

13. S. Darcy, Journal of Hospitality and Tourism Management, 16 (1), 32-44 (2009)

14. K. Samursky, National Geographic of Russia, 11, 50 (2009.)

15. A.I. Seselkin, Theory and practice of physical education, 3, 44-46 (2016)

16. A.I. Seselkin, Uchenye zapiski universiteta imeni P.F. Lesgafta, 11 (129), 241-246 (2015)

17. E.A. Sigida, Service Plus, 9(2), 64-72 (2015)

18. O.A. Stepurenko, Collection of proceedings of international scientific conferences, 217 -225 (2018)

19. T.A. Sycheva, Society: sociology, psychology, pedagog, 11, 89-92 (2017)

20. V.Sh. Khetagurova, Tourism and hospitality through the prism of innovation, 115-118 (2018)

21. D. Gura, M. Kuzyakina, I. Gribkova, IOP Conference Series: Earth and Environmental Science, 403(1), 012176 (2019) DOI: 10.1088/1755-1315/403/1/012176

22. D.A. Gura, Y.V. Dubenko, G.G. Shevchenko, E.E. Dyshkant, N.I. Khusht, Lecture Notes in Civil Engineering book series, 50, 185-190 (2020) DOI: 10.1007/978-98115-0454-9_19

23. D. Gura, Y. Dubenko, I. Markovskiy, S. Pshidatok, IOP Conference Series: Earth and Environmental Science, 403(1), 012185 (2019) DOI: 10.1088/17551315/403/1/012185

24. D.A. Gura, I.G. Markovskii, B.A. Hahuk, S.K. Pshidatok, IOP Conference Series: Materials Science and Engineering, 698(4), 044014 (2019) DOI: 10.1088/1757899X/698/4/044014

25. V. Shishkina, D. Gura, I. Gribkova, M. Bykova, IOP Conference Series: Materials Science and Engineering, 698(6), 066016 (2019) DOI: 10.1088/1757899X/698/6/066016 